\title{
FLUID BALANCE DURING TAEKWONDO TRAINING
}

\author{
EQUILÍBRIO HIIDRICO DURANTE TREINAMENTO DE TAEKWONDO \\ Original Article \\ EQUILIBRIO HIDDICO DURANTE ENTRENAMIENTO DE TAEKWONDO \\ ARTIGO ORIGINAL \\ Artículo Original
}

Felipe Gomes Belfort' ${ }^{\prime}$ (D) (Physical Education Professional)

Paulo Roberto dos Santos Amorim ${ }^{1}$ (ID (Physical Education Professional)

Carlos Enrique Silva' (ID)

(Physical Education Professional)

Cassia Farias Fernandes Gonçalves' (iD (Physical Education Professional)

Priscila Rita Niquini' (ID

(Physical Education Professional)

Rafael Pires Silva' (DD)

(Physical Education Professional)

João Carlos Bouzas Marins' (iD)

(Physical Education Professional)

1. Universidade Federal de Viçosa, Department of Physical Education, Viçosa, MG, Brazil.

\section{Correspondence:}

João Carlos Bouzas Marins. Universidade Federal de Viçosa, Department of Physical Education, Laboratório de Performance Humana. Av. PH Rolfs, SN, Centro Universitário, Centro, Viçosa, MG, Brazil. 36570-000.

joaobouzas@yahoo.com.br

\section{ABSTRACT}

Introduction: Dehydration has been described as one of the main factors of reduced performance in combat sports activities, leading to death in extreme cases. Objective:To investigate the pre-training hydration status and changes in fluid homeostasis during two taekwondo training sessions. Methods: Eighteen male college athletes (age $22.6 \pm$ 3.37 years) were assessed. The study design aimed to reproduce the conditions of a 90 -minute taekwondo training session, divided into three stages: a) warm-up exercises (20 min); b) poomsae (30 min) and c) technical training (40 $\mathrm{min}$ ). The athletes had ad libitum water intake during training. To assess the hydration status we considered body mass (BM), the amount of liquid consumed and urine output, which enabled us to establish absolute and relative fluid loss in $\mathrm{kg}$ and percentage as well as the sweating rate. We also considered urine specific gravity (USG), urine color (U-COL), and subjective sensation of thirst ( $\left.S_{\text {thirst }}\right)$ before and after the training session. Pre- and post-training results were compared separately in each session and between sessions. Results: There was a significant difference $(P<0.05)$ in pre-training BM between the two days of training. There was a significant difference $(P<0.05)$ in the final BM on both days of the experiment. Most subjects had relative dehydration below 2\%. A significant difference $(\mathrm{P}<0.05)$ was recorded pre and post training for $\mathrm{U}-\mathrm{COL}$ and $\mathrm{S}_{\text {thirst }}$ with the highest rates obtained at the end of each session. Participants always started training at a low dehydration status (USG >1,020 g.ml-1). Conclusions: The athletes tended to start the training sessions in dehydration status, which increases over the course of the training. Ad libitum water intake was not sufficient to balance fluid loss. Changes in fluid levels between sessions were similar. Level of Evidence Il; Therapeutic Studies Investigating the Results Level of Treatment.

Keywords: Sports nutritional physiological phenomena; Dehydration; Fluid therapy; Martial arts.

\section{RESUMO}

Introdução: A desidratação tem sido descrita como um dos principais fatores de redução de desempenho em atividades de luta, levando, em casos extremos, à morte. Objetivos: Investigar o estado da hidratação antes do treino e as alterações no balanço hídrico corporal durante dois treinamentos de taekwondo. Métodos: Foram avaliados 18 atletas universitários do sexo masculino (22,6 $\pm 3,37$ anos). O desenho do estudo procurou reproduzir uma condição de treinamento de taekwondo com duração de 90 minutos, dividido em três etapas: a) aquecimento (20 min.), b) poomsae (30 min.) e c) treino técnico (40 min.). Durante o treino, adotou-se o consumo de água ad libitum. Para avaliar o estado de hidratação, considerou-se a massa corporal (MC), a quantidade de líquido consumido e o volume de urina produzido, o que permitiu estabelecer a perda hídrica absoluta e relativa em kg e porcentagem, além da taxa de sudorese. Foi considerada ainda a gravidade específica da urina (GEU), bem como sua coloração (COL-U), além da sensação subjetiva de sede ( $S S_{\text {ede }}$ ) antes e depois do treino. Os resultados antes e depois do treino foram comparados de forma isolada em cada sessão, assim como entre as sessões. Resultados: Houve diferença significativa $(P<0,05)$ da MC pré-treinamento entre os dois dias de treino. Houve redução significativa $(P<$ $0,05)$ da MC final em ambos os dias de experimento. A maior parte dos avaliados apresentou desidratação relativa inferior a 2\%. Registrou-se diferença significativa $(P<0,05)$ antes e depois do treino para COL-U e para SS eder com os maiores índices obtidos ao final de cada sessão. Os participantes sempre iniciaram o treinamento em leve estado de desidratação (GEU > $1.020 \mathrm{~g} \cdot \mathrm{ml}^{-1}$ ). Conclusões: Os atletas tendem a iniciar os treinamentos em estado de desidratação, que se amplia durante o treino. O consumo de líquidos ad libitum não foi suficiente para equilibrar a perda hidrica. As alterações hídricas entre as sessões foram semelhantes. Nível de Evidência ll; Estudos terapêuticos-Investigação dos resultados do tratamento.

Descritores: Fenômenos fisiológicos da nutrição esportiva; Desidratação; Hidratação; Artes marciais.

\section{RESUMEN}

Introducción: La deshidratación ha sido descrita como uno de los principales factores de reducción del desempeño en actividades de lucha, llevando, en casos extremos, a la muerte. Objetivos: Investigar el estado de la hidratación antes del entrenamiento y las alteraciones en el balance hídrico corporal durante dos entrenamientos de taekwondo. Métodos: Se evaluaron 18 atletas universitarios del sexo masculino (22,6 $\pm 3,37$ años). El diseño del estudio intentó reproducir una condición de entrenamiento de taekwondo con duración de 90 minutos, dividido en tres etapas: a) calentamiento (20 min); b) poomsae (30 min); y c) entrenamiento técnico (40 min). Durante el entrenamiento, se adoptó el consumo de agua ad libitum. Para evaluar el estado de hidratación, se consideró la masa corporal (MC), la cantidad de líquido consumido y el volumen de orina producido, lo que permitió establecer la pérdida hídrica absoluta y relativa en $\mathrm{kg}$ y porcentaje, además de la tasa de sudoración. Fue considerada además la gravedad específica de la orina (GEO), así como 
su coloración (COL-O), además de la sensación subjetiva de sed (SS ${ }_{e d}$, antes y después del entrenamiento. Los resultados antes y después del entrenamiento fueron comparados de forma aislada en cada sesión, así como entre las sesiones. Resultados: Hubo diferencia significativa $(P<0,05)$ de la MC preentrenamiento entre los dos días de entrenamiento. Hubo reducción significativa $(P<0,05)$ de la MC final en ambos días de experimento. La mayor parte de los evaluados presentó deshidratación relativa inferior a $2 \%$. Se registró diferencia significativa $(P<0,05)$ antes y después del entrenamiento

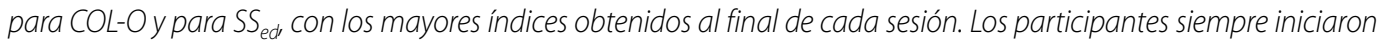
el entrenamiento en leve estado de deshidratación (GEO > 1.020 g.ml-1). Conclusiones: Los atletas tienden a iniciar los entrenamientos en estado de deshidratación, que se amplía durante el entrenamiento. El consumo de líquidos ad libitum no fue suficiente para equilibrar la pérdida hídrica. Las alteraciones hídricas entre las sesiones fueron semejantes. Nivel de Evidencia ll; Estudios terapéuticos - Investigación de los resultados del tratamiento.

Descriptores: Fenómenos fisiológicos en la nutrición deportiva; Deshidratación; Fluidoterapia; Artes marciales.

\section{INTRODUCTION}

Dehydration is a factor that, depending on its magnitude, impairs physical performance both in training and in competition. ${ }^{1,2}$

Combat sports usually take place indoors in places with little ventilation and with clothing that hinders the exchange of heat with the environment, as is the case of judo, karate, jiu-jitsu and taekwondo. In addition, athletes use protective equipment, such as gloves, chest guards, shin (tibia)/elbow pads and helmets, usually made of plastic, sponges and other impermeable materials, which hinders body thermoregulation, thus increasing fluid loss.

Strategies such as fluid restriction are also usually employed in combat sports, e.g., boxing, judo, karate, jiu-jitsu and taekwondo. ${ }^{3-6}$ This triggers signs and symptoms of chronic dehydration, which can reach values corresponding to a $3 \%$ to $5 \%$ loss of total body mass. ${ }^{6}$ In addition, athletes and coaches face a lack of information on the problems caused by this dehydration, and are not familiar with the recommended strategies to maintain an adequate hydration status. These factors in conjunction can be detrimental to the athlete's health and impair his or her performance.

Studies on fluid loss in sports such as soccer, running or judo are common, but in taekwondo, few studies have investigated this behavior. ${ }^{5,8-12}$ Thus, it is necessary to identify how the fluid balance resulting from a typical taekwondo training session behaves. Accordingly, the aim of this study was to investigate the initial pre-workout hydration status and changes in fluid balance during two taekwondo training sessions.

\section{MATERIALS AND METHODS}

\section{Sample}

We assessed eighteen men ( $22.6 \pm 3.37$ years) who are members of a university taekwondo team. The inclusion criteria were as follows: a) at least six months of participation in the sport; b) regular training on at least three days a week, with sessions lasting approximately 90 minutes.

All subjects were considered apparently healthy, as assessed by the PAR$\mathrm{Q}^{13}$ questionnaire, with negative answers to all questions, and the coronary risk questionnaire ${ }^{14}$ indicating that the subjects had a coronary risk classified as "low". The subjects also completed the advanced anamnesis questionnaire available in Avaesporte software (Esportes Sistemas, MG, Brazil) version 1.0, which highlighted the nonexistence of a history of chronic and acute conditions. Moreover, the subjects were nonsmokers and were not taking drug products that could alter the study variables, such as diuretics; neither did they drink alcohol on a regular basis. No female volunteers were enrolled in the study.

All the volunteers were briefed on the dynamics of the study and its main objectives, risks and benefits, and all queries were clarified before they signed the consent form. All the study procedures were submitted to the (human research) institutional review board of Universidade Federal de Viçosa, under number 40928260029.

\section{Study design}

Standardized taekwondo training sessions lasting 90 minutes each were held on two different days with a 1-week interval, divided into three parts: a) 20 minutes of warm-up with generalized calisthenics exercises; b) 30 minutes of poomsae, which are technical movements of taekwondo representing a fight against an imaginary opponent; and c) 40 minutes focusing on fighting techniques.

To establish hydration control parameters, we considered the following: body mass (BM), urine, the subjective perception of thirst $\left(S_{\text {thirst }}\right)$ and fluid intake. Further information on each control element can be found below.

\section{Body mass}

The athletes were instructed to maintain their usual hydration and nutrition strategies throughout the cycle of participation in the study. Before the first weigh-in, the athletes urinated to completely empty their bladders. This procedure took place approximately 20 minutes before the start of the exercise dynamics, as well as shortly after their completion. The athletes were weighed on a digital scale (Soehnle', Spain) with an accuracy of $0.01 \mathrm{~kg}$, wearing only their underwear. With the weight difference shown on the scale, the fluid intake, and urine output during and/or immediately after the training session, it was possible to establish a series of parameters related to fluid balance, such as absolute and relative dehydration, both expressed both in $\mathrm{kg}$ and \%, as well as the total loss of sweat expressed in $\mathrm{ml}$ and the sweating rate in $\mathrm{ml} / \mathrm{min}$.

Absolute dehydration considers the total loss of water that occurred throughout the training period, which corresponds to the difference in weight between pre- and post-training periods, plus the fluid intake and urine output over the course of and/or after the end of the exercise. Relative dehydration, on the other hand, considers only the pre- and post-training weight difference. In both situations the results can be expressed in kg or percentage of loss, based on the initial body mass. When considering the amount of fluid intake, and assuming that each $1 \mathrm{~g}$ of difference in body weight before and after training corresponds to $1 \mathrm{ml}$ of sweat produced, it is possible to calculate the total sweat loss in liters. In turn, the sweating rate $\left(\mathrm{mL} . \mathrm{h}^{-1}\right)$ can be established by dividing this value by the minutes of activity, which in this case came to 90 minutes.

\section{Urinalysis}

Urine samples were collected in a suitable plastic container, identified individually, about 20 minutes before and shortly after the training sessions. To analyze urine specific gravity (USG) we used a portable refractometer (model A300, ATAGO Co, Tokyo, Japan). The samples were classified by color as proposed by Armstrong et al. ${ }^{15}$ at eight levels, where it is possible to assess the level of hydration. 


\section{Analysis of fluid intake}

Each athlete had an opaque squeeze bottle with a capacity of approximately $600 \mathrm{ml}$ identified with his or her name, enabling us to establish the actual fluid intake during training. The type of fluid offered on the two days was exclusively water ad libitum.

The mass of the bottles was disregarded and the bottles were later filled to the brim with water. A digital scale (Plenna" MSI Inc., USA) with $0.01 \mathrm{~g}$ accuracy was used to control the fluid intake. During the training sessions, athletes were only able to drink from their own bottles, and were not allowed to share or even waste the liquid. As soon as the athletes had consumed all the liquid contained in the bottle, the bottle was weighed and once again topped up with the beverage. Final and initial values were noted down to avoid the nonconsumption of water due to its shortage. At the end of the training sessions, the bottles of all the participants were collected, and their liquid content was immediately measured and recorded.

\section{Analysis of the subjective sensation of thirst}

Before and after each training session, athletes were asked questions about their sensation of thirst based on the use of a specific nine-point scale. ${ }^{16}$ This scale presents extreme values from 1 (no thirst) to 9 (intense thirst). This procedure takes into account the fact that the sensation of thirst is associated with dehydration exceeding $2 \%$ of body weight..$^{17}$

Environmental conditions of the study

The two training sessions were held in the same place, with the following dimensions: width of 12.5 meters, length of 18.6 meters and height of 4.5 meters, without mechanical ventilation appliances. The annual data collection period was in the spring, with the data collection dynamics taking place at night. The weather conditions were 23.3 $\pm 1.6^{\circ} \mathrm{C}$ and $77.6 \pm 3.4 \% \mathrm{RH}$ on the first day of the test, and $23.4 \pm 1.3^{\circ} \mathrm{C}$ and $79.1 \pm 3.7 \% \mathrm{RH}$ on the second day. Room temperature and relative humidity were both measured using the wet bulb globe temperature indicator (TGM 100, Homis", Brazil) at 30-minute intervals, and the mean was established during the training session.

\section{Statistical analysis}

The data were tested for distribution and subsequent descriptive analysis by calculating central tendency and variability measures. Variables such as total sweat production (L), sweat production rate $\left(L . h^{-1}\right)$, fluid intake (L), absolute and relative fluid loss were analyzed using Student's t-test to verify the existence of a difference in the data that showed normal distribution, supplemented by the Mann-Whitney test for nonparametric data.
Analysis of variance (ANOVA) for two factors $(2 \times 2)$, i.e., time (pre-and post-measurements) and day ( $1^{\text {st }}$ and $2^{\text {nd }}$ ), was used for USG, thirst and body mass, while Holm-Sidak post hoc test was employed for variables in which ANOVA showed statistical difference. The statistical program Sigma Stat ${ }^{\oplus}$ version 3.0 was used. The level of probability $P<0.05$ was chosen as a criterion for statistical significance.

\section{RESULTS}

Table 1 lists changes in the athletes'body mass, absolute and relative fluid loss, both in $\mathrm{kg}$ and in \%, total sweat loss, sweating rate, amount of fluid intake, USG, urine color and $S_{\text {thirst. }}$.

Regarding the variations between the two training sessions, there was a significant difference $(P<0.05)$ only in body mass both in pre-training and in post-training, with the highest body mass observed in both cases (pre and post) on the first day of evaluation.

When the training effect (pre vs. post) was analyzed, there was a significant reduction $(P<0.05)$ in body mass on both days of the experiment, while there was a significant increase in the urine color scales and $\mathrm{S}_{\text {thirst }}$ (Table 1). The other parameters assessed were considered stable. Among the athletes who started the first training session, $72 \%$ had USG values equal to or greater than 1,020 , while in the second session the percentage was $77 \%$. At the end of the training period, the percentage remained the same as that observed at the start of the training period.

Only one athlete exhibited weight gain at the end of the session, and none urinated during the training session. Two athletes experienced fluid loss greater than $2 \%$ of body weight in the first session and only one fighter in the second. None of the athletes refrained from drinking fluids during training. There were no dropouts over the course of the data collection dynamics.

\section{DISCUSSION}

When we compared the two days of training, only the initial body mass showed significantly higher values on the first day. However, it should be noted that this difference was $\approx 700 \mathrm{~g}$ or close to $1 \%$, a range of daily body mass variation considered normal on account, for example, of the fecal volume of food consumed throughout the day. ${ }^{17}$

The absence of significant differences in the other parameters analyzed, when we compared the two days of training, indicates that a follow-up of changes in these fluid parameters on just a single typical day of training can provide important information on the dynamics of fluid loss and, consequently, assist in planning the type of hydration strategy to be adopted.

Table 1. Changes in the variables used to quantify the athletes' pre- and post-training hydration status on the two days of collection.

\begin{tabular}{|c|c|c|c|c|c|c|c|}
\hline & \multicolumn{3}{|c|}{$1^{\text {St }}$ day of training } & \multicolumn{3}{|c|}{$2^{\mathrm{Nd}}$ day of training } & \multirow[t]{2}{*}{$1^{\text {St }}$ day vs $2^{\text {nd }}$ day ( $p$} \\
\hline & Mean(SD) & Min. & Max. & Mean(SD) & Min. & Max. & \\
\hline Pre-Tr. BM (kg) & $76.1(8.31)$ & 64.5 & 90.5 & $75.37(7.86)$ & 64.2 & 90 & $P=0.012$ \\
\hline Post-Tr. BM (kg) & $75.50(8.31)^{\#}$ & 64.1 & 90.2 & $74.79(7.81)^{\#}$ & 63.5 & 89.6 & $P=0.009$ \\
\hline AFL (kg) & $0.59(0.58)$ & -0.5 & 2 & $0.57(0.49)$ & 0 & 2 & $P=0.879$ \\
\hline RFL (\%) & $0.78(0.78)$ & -0.7 & 2.84 & $0.76(0.62)$ & 0 & 2.48 & $P=0.882$ \\
\hline Total Sweat Loss (L) & $1.16(0.62)$ & 0.32 & 2.75 & $1.05(0.51)$ & 0.56 & 2.64 & $P=0.405$ \\
\hline Sweating Rate $\left(L . h^{-1}\right)$ & $0.77(0.41)$ & 0.21 & 1.83 & $0.70(0.34)$ & 0.37 & 1.76 & $P=0.405$ \\
\hline AFI (L) & $0.56(0.33)$ & 0.05 & 1.19 & $0.47(0.26)$ & 0.14 & 1.04 & $P=0.166$ \\
\hline Pre-Tr. USG $\left(\mathrm{g} . \mathrm{ml}^{-1}\right)$ & $1021(8.52)$ & 1002 & 1031 & $1023(8.35)$ & 1003 & 1031 & $P=0.360$ \\
\hline Post-Tr. USG (g.ml'-1) & $1023(8.05)$ & 1004 & 1032 & $1025(7.76)$ & 1005 & 1036 & $P=0.223$ \\
\hline Pre-Tr. COU (S from 1 to 8) & $3.77(1.30)$ & 1 & 6 & $3.88(1.13)$ & 1 & 5 & $P=0.578$ \\
\hline Post-Tr. COU (S from 1 to 8) & $4.38(1.37)^{*}$ & 2 & 8 & $4.77(1.55)^{*}$ & 2 & 7 & $P=0.299$ \\
\hline Pre-Train. $S_{\text {thirst }}$ (S from 1 to 9) & $4.11(1.9)$ & 1 & 7 & $4.72(1.84)$ & 2 & 7 & $P=0.255$ \\
\hline Post-Train. $S_{\text {thirst }}$ (S from 1 to 9) & $5.61(1.28)^{* *}$ & 3 & 7 & $6.16(0.98)^{* *}$ & 4 & 8 & $P=0.068$ \\
\hline
\end{tabular}

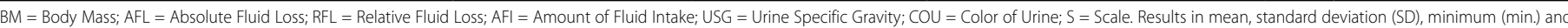

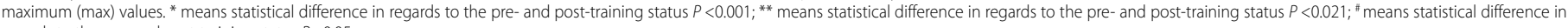
regards to the pre- and post-training status $P<0.05$. 
The average variation in relative fluid loss was $600 \mathrm{~g} \approx 600 \mathrm{ml}$ on the first day and $580 \mathrm{~g} \approx 580 \mathrm{ml}$ on the second, thus corresponding to less than $1 \%$ of body weight. These values can be considered low due to the fluid loss recorded in other studies of martial arts in training, as shown in Table 2, which usually exceed 3\% dehydration. ${ }^{5}$ However, acute losses that exceed $4 \%$ have been documented in various types of martial arts, mainly around the time of competitions., ${ }^{3,4}$ The lower fluid loss observed in the group assessed in this study may have resulted from the thermal conditions in which the study was conducted, besides the amount of fluid intake over the course of the training period (Table 1), which, despite proving insufficient to completely preserve body mass, helped attenuate dehydration levels, indicating that ad libitum intake minimizes a potential high fluid loss. An alternative action for prescribing the volume of fluids to be offered to the individual athlete to avoid hyper- or hypohydration uses knowledge of the athlete's fluid loss in $\mathrm{ml} / \mathrm{min}$ in certain environmental conditions as a reference. For example, considering an athlete who weighs $76.1 \mathrm{~kg}$ with a sweating rate of 0.77 $\mathrm{L.h}^{-1}$, this will correspond to a loss of $12.83 \mathrm{ml} / \mathrm{min}$. If regular hydration intervals are adopted every 15 minutes, this athlete should consume around $192.49 \mathrm{ml} \approx 190 \mathrm{ml}$ at each interval time point.

Table 2 shows the variation in body mass in different types of martial arts in three studies. ${ }^{3-5}$ In two studies ${ }^{3,4}$ the fluid loss recorded was greater than $2.5 \mathrm{~kg}$ and $3 \%$ of BM, values that far exceed the value observed in this study (Table 1). However, it should be noted that in the follow-up carried out by Kazemi et al. (2011), the body mass recorded at the end of the training period exceeded the initial mass by around $900 \mathrm{~g}$, indicating hyperhydration. This should not be considered ideal either, since at high levels it is regarded as a condition that facilitates the onset of hyponatremia, being more frequently observed in marathon runners at the end of a race.

The main reason for the occurrence of dehydration in fighters is the fact that they are not in the habit of maintaining hydration during training. ${ }^{18,19}$ In this particular study, two factors may have determined the results obtained: the fact that they are college students, thus entailing greater access to information about sports nutrition and its importance; and the fact that they had a college educated technical team assisting in this awareness building exercise.

The mean relative fluid loss of less than $1 \%$ of body weight suggests a low risk of problems caused by dehydration. This finding corroborates the recommendations for maintaining sports performance and health, in which the percentages of relative fluid loss should not be greater than $2 \%$ of body mass loss. ${ }^{17}$ In extreme cases of dehydration, athletes often adopt acute fluid loss strategies in an irresponsible and uncontrolled manner ${ }^{4}$ and arrive at the training location with dehydration levels that are already extremely high. This situation will be exacerbated by the fluid loss generated through training, thus leading to conditions conducive to cardiac arrest and death.
The mean absolute weight loss of the college athletes before and after training was close to $1.0 \mathrm{~kg}$. This figure is lower than that found in amateur boxers, ${ }^{3}$ who achieved body mass losses greater than $2.0 \mathrm{~kg}$ after training. Brito et al., ${ }^{4}$ when evaluating taekwondo, judo, karate and jiu-jitsu fighters through questionnaires, showed that the losses of body mass in these combat sports can be greater than $5 \mathrm{~kg}$ in a competition period.

The differences between the results of this particular study and those of the studies mentioned in table 2 may also be due to the fact that each sport has specific characteristics in terms of environmental conditions, clothing and a series of other internal and external factors, which means fluid loss is specifically related to the sport in question.

Regarding sweat production, this study found values close to 11.66 $\mathrm{ml} / \mathrm{min}$, higher than those found by other studies with fighters who train at a gym [5 to $9.58 \mathrm{ml} / \mathrm{min}$ ]. ${ }^{20}$ These differences may be caused essentially by the environmental conditions and characteristics of physical exertion, which can be more continuous and intense than taekwondo. There are extreme cases in which values above $3.0 \mathrm{~L} . \mathrm{h}^{-1}$ [50 ml/min] were recorded, with sweating rates between $1 \mathrm{~L}$ and $2{\mathrm{~L} . \mathrm{h}^{-1}}^{-1}[16.6-33.3 \mathrm{ml} / \mathrm{min}]$ recorded on a regular basis, particularly in cyclic sports.

The ad libitum fluid intake was close to $500 \mathrm{ml}$, not sufficient to replace $100 \%$ of the amount of fluid lost. In a taekwondo training environment there are plenty of opportunities to drink fluids. Athletes were able to drink more fluids during training breaks. Among the athletes assessed on the first day, one lost approximately $3 \mathrm{~L}$ and another $2.5 \mathrm{~L}$. Fluid intake was $0.7 \mathrm{~L}$ and $0.6 \mathrm{~L}$, respectively, values well below the recommended fluid replenishment level. This emphasizes the need to establish individual fluid loss, allowing the preparation of specific hydration strategies, especially since most fighters reportedly only drink fluids when they feel thirsty, which in itself is an indicator of dehydration. ${ }^{20}$

To achieve a better fluid balance, fluid intake in the same proportion as fluid loss recorded over the course of workouts has been recommended ${ }^{1}$ during training sessions. This implies the need to have established the predicted loss in $\mathrm{ml} / \mathrm{min}$ on an individual basis, anticipating scheduled hydration at a certain time interval, usually between 10 and 20 minutes.

Some international and national guidelines recommend fluid intake before, during and after physical activity. ${ }^{1,2}$ Thus, the athlete must start the activity in a euhydration state, thereby optimizing their sports performance. ${ }^{1,2}$ USG quantifies the hydration status, and is a useful strategy for routine application. USG values $<1,020 \mathrm{~g} \cdot \mathrm{ml}^{-1}{ }^{1}{ }^{21}$ represent a euhydration status. Most of the athletes started the activity in a state of mild dehydration on both training days, which reinforces the need to make them aware of the maintenance of constant hydration outside the training period. The daily use of the refractometer is a low-cost, practical and efficient strategy to estimate the hydration status of athletes, especially before starting to exercise. However, it is important to associate this practice with daily control of body mass before and after training, along with urine color and $S_{\text {thirst }}$ for the final classification of the athlete's fluid balance. ${ }^{22}$

Table 2. Variation of body mass in different martial arts.

\begin{tabular}{|c|c|c|c|c|c|c|c|}
\hline Study & Combat Sport & $\mathbf{N}$ & Sex & Initial weight (kg) & Final weight (kg) & $\begin{array}{c}\text { Absolute weight } \\
\text { loss }(\mathrm{kg})\end{array}$ & $\begin{array}{c}\text { Relative weight } \\
\text { loss (\%) }\end{array}$ \\
\hline Hall $(2002)^{3}$ & Amateur boxing & 16 & $M$ & $72.20 \pm 11.16$ & $68.50 \pm 10.79$ & $3,7^{€}$ & $5,16^{€}$ \\
\hline Kazemi et al. $(2011)^{5}$ & Taekwondo & 108 & $M / F$ & $60.3 \pm 11.9$ & $61.4 \pm 11.7$ & $\#$ & $\#$ \\
\hline \multirow{4}{*}{ Brito et al., $(2012)^{4}$} & Taekwondo & \multirow{4}{*}{580} & \multirow{4}{*}{$M / F$} & \multirow{4}{*}{$74.5 \pm 9.7$} & \multirow{4}{*}{$\beta$} & $3.2 \pm 1.2^{*}$ & $4.3^{¥}$ \\
\hline & Judo & & & & & $5.6 \pm 2.2^{*}$ & $8.5^{*}$ \\
\hline & Karate & & & & & $2.5 \pm 1.1^{¥}$ & $3.6^{¥}$ \\
\hline & Jiu-jitsu & & & & & $2.9 \pm 1.5^{*}$ & $4.1^{*}$ \\
\hline
\end{tabular}

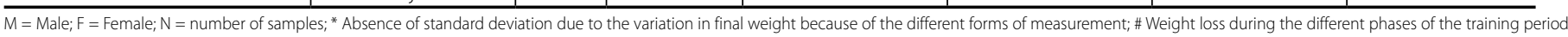

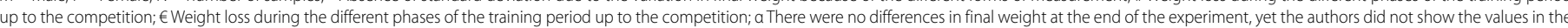

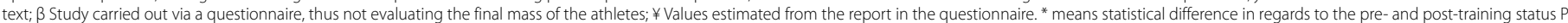
$<0.001$; ** means statistical difference in regards to the pre- and post-training status $\mathrm{P}<0.021 ;$; means statistical difference in regards to the pre- and post-training status $\mathrm{P}<0.05$. 
No significant increases in the athletes' USG were observed after the activities, which suggests that the athletes tended to maintain their initial status of mild dehydration even with ad libitum fluid intake. A recent systematic review demonstrates that significant increases in USG after training are common in fighters, ${ }^{23}$ which can impair athletic performance. However, maintaining this chronic state of dehydration is not recommended for the preservation of sports performance and especially health. USG increases are common when dehydration occurs, ${ }^{22}$ as was the case of this study.

Urine color is an interesting indicator of the hydration level. ${ }^{24} \mathrm{An}$ "almost transparent" color is considered to be a strong indicator that there is a good level of hydration in the body, whereas the darker the color, the higher the level of dehydration. In this study there was a significant increase in the urine color scale, corroborating the $S_{\text {thirst }}$ findings in this study. Conversely, there was a statistically significant reduction $(P<0.05)$ of BM (pre vs. post training). Urine color was sensitive to capture the recorded fluid loss - a parameter also observed in fighters participating in other combat sports. ${ }^{23}$ The $S_{\text {thirst }}$ results also point to a significant increase at the end of both sessions. This behavior can be considered normal, as signs and symptoms of dehydration influence the increase in plasma osmolarity, so that blood, when flowing into the hypothalamus, generates the thirst stimulus ${ }^{1}$ in direct proportion to its magnitude. The values obtained remained at non-extreme levels, emphasizing that the dehydration was of minor magnitude, less than $1 \%$. The low number of subjects with fluid loss above $2 \%$ probably determined the rates obtained. In combat sports in general, actions undertaken in the training environment, including a ban on drinking fluids, are reasonably common. These are even encouraged by coaches aiming at an acute weight loss, in which the $S_{\text {thirst }}$ is supposed to be disregarded. Under these conditions, it is undeniable that a high level of dehydration will be achieved with a negative influence on the athlete's performance ${ }^{17}$ and particularly on their health, as high levels of dehydration increase the risk of hyponatremia, hyperthermia, rhabdomyolysis, acute renal failure, coma and death.

The results of this study were obtained in a training environment characterized as having "moderate" thermal stress. In environments with more extreme heat conditions, the impact of fluid loss would be greater. We suggest further studies on the fluid balance of taekwondo athletes, varying the training intensity, the environmental conditions and the type of beverage offered, or even carrying out studies with women.

\section{CONCLUSIONS}

Regardless of the training session, athletes tend to start the workout it in a state of dehydration, with this condition increasing over the course of the session. Ad libitum fluid intake was not sufficient to fully balance fluid loss. The levels of dehydration obtained were considered moderate, but sufficient to increase the subjective perception of thirst and urine color.

All authors declare no potential conflict of interest related to this article

AUTHORS' CONTRIBUTIONS: Each author made significant individual contributions to this manuscript. Felipe Gomes Belfort: conception, planning, data acquisition, analysis, discussion, interpretation, writing of the text, review and approval of the final version of the text; Paulo Roberto dos Santos Amorim: analysis, statistical treatment, discussion, interpretation, writing of the text, review and approval of the final version of the text; Carlos Enrique Silva, Cassia Farias Fernandes Gonçalves, Priscila Rita Niquini, Rafael Pires Silva: planning, data acquisition, analysis, discussion, interpretation; João Carlos Bouzas Marins: conception, planning, data acquisition, analysis, discussion, interpretation, writing of the text, review and approval of the final version of the text.

\section{REFERENCES}

1. American College of Sports Medicine. American College of Sports Medicine position stand. Exercise and fluid replacement. Med Sci Sport Exerc. 2007;39(2):377-90.

2. Sociedade Brasileira de Medicina do Exercício e do Esporte. Modificações dietéticas, reposição hídrica, suplementos alimentares e drogas: Comprovação de ação ergogênica potenciais riscos para a saúde. Rev Bras Med do Esporte. 2009;15(3):3-12.

3. Hall CJ. Effects of rapid weight loss on mood and performance among amateur boxers. Br J Sports Med. 2002;35(6):390-5.

4. Brito CJ, Roas AFCM, Brito ISS, Marins JCB, Córdova C, Franchini E. Methods of body-mass reduction by combat sport athletes. Int J Sport Nutr Exerc Metab. 2012;22(2):89-97.

5. Kazemi M, Rahman A, De Ciantis M. Weight cycling in adolescent Taekwondo athletes. J Can Chiropr Assoc. 2011;55(4):318-24.

6. Barley OR, Chapman DW, Abbiss CR. Weight Loss Strategies in Combat Sports and Concerning Habits in Mixed Martial Arts. J Int J Sport Physiol Perform Accept Date. 2018;13(7):933-9.

7. Marins JCB. Hidratação na atividade física e no esporte. Fontoura., editor. Jundiaí.: Fontoura.; 2011. 304 p.

8. Pallarés JG, Martínez-Abellán A, López-Gullón JM, Morán-Navarro R, De la Cruz-Sánchez E, Mora-Rodríguez R. Muscle contraction velocity, strength and power output changes following different degrees of hypohydration in competitive olympic combat sports. J Int Soc Sports Nutr. 2016;13:10.

9. Hoffman MD, Goulet EDB, Maughan RJ. Considerations in the use of body mass change to estimate change in hydration status during a 161-kilometer ultramarathon running competition. Sport Med. 2018;48(2):243-50.

10. Rivera-Brown AM, De Félix-Dávila RA. Hydration status in adolescent judo athletes before and after training in the heat. Int J Sports Physiol Perform. 2012;7(1):39-46.

11. Kutlu M, Guler G. Assessment of hydration status by urinary analysis of elite junior taekwon-do athletes in preparing for competition. J Sports Sci. 2006;24(8):869-73.

12. Kazemi M, Shearer H, Young SC. Pre-competition habits and injuries in taekwondo athletes. BMC Musculoskelet Disord. 2005;6:26.
13. Chisholm D, Collis M, Kulak L, Davenport W, Gruber N. Physical activity readiness. Br Columbia Med Assoc. 1975;17:375-8

14. Michigan Heart Association. RISKO. Lancet. 1973;2:243-4.

15. Armstrong LE, Maresh CM, Castellani JW, Bergeron MF, Kenefick RW, LaGasse KE, et al. Urinary indices of hydration status. Int J Sport Nutr. 1994;4(3):265-79.

16. Lieberman HR, Bathalon GP, Falco CM, Kramer FM, Morgan CA, Niro P. Severe decrements in cognition function and mood induced by sleep loss, heat, dehydration, and undernutrition during simulated combat. Biol Psychiatry. 2005;57(4):422-9.

17. Casa DJ, Clarkson PM, Roberts WO. American College of Sports Medicine roundtable on hydration and physical activity: consensus statements. Curr Sports Med Rep. 2005;4(3):115-27.

18. Alflen D, Reis J, Moreira V, Lima LD da C, Oliveira J. Caracterização das práticas de hidratação em atletas de karatê do estado de Rondônia. Coleção Pesqui em Educ Física. 2009;8(4):85-92.

19. Brito CJ, Marins JCB. Caracterização das práticas sobre hidratação em atletas da modalidade de judô no estado de Minas Gerais. R bras Ci e Mov. 2005;13(2076):59-73.

20. Loiola PC, Benetti MV, Durante JG, Frade RE, Viebig RF. Avaliação da porcentagem de perda de peso e taxa de sudorese após o treino de lutadores de uma academia no estado de São Paulo. Rev Bras Nutr Esportiva. 2019;9(49):74-83.

21. American College of Sports Medicine. Position stand. Nutrition and athletic performance. Medicine and Science in Sports and Exercise. Med Sci Sports Exerc. 2009;41(3):709-31.

22. Fernández-Elías VE, Martinez-Abellán A, López-Gullón JM, Morán-Navarro R, Pallarés JG, De La Cruz-Sánchez $E$, et al. Validity of hydration non-invasive indices during the weightcutting and official weigh-in for olympic combat sports. PLoS One. 2014;9(4):e95336.

23. Zubac D, Paravlic A, Reale R, Jelaska I, Morrison SA, Ivancev V. Fluid balance and hydration status in combat sport Olympic athletes: a systematic review with meta-analysis of controlled and uncontrolled studies. Eur J Nutr. 2019;58(2):497-514.

24. Sawka MN, Coyle EF. Influence of body water and blood volume on thermoregulation and exercise performance in the heat. Exerc Sport Sci Rev. 1999;27:167-218. 